\title{
ПРОБЛЕМАТИКА ЖІНОЧОЇ ОБРАЗНОСТІ У ТВОРЧОСТІ МАРІЇ КУЛІКОВСЬКОї
}

Статтю присвячено темі освітлення образу жінки у творчості української художниці Марії Куліковської.

На основі аналізу й систематизачї̈ наукових та публічистичних джерел було описано специфіку сучасного мистецутва в Украӥні, щчо порушує сочіологічно важливі темі в аспектах жіночої образності та тілесності в різних видах мистецтвва, авторства Марії Куліковської, а саме: відео-арт, скульптура, малюнки та перформативні практики.

Досліджено роботи, щзо зачіпають інтерпретацію фемінності відносно особистих внутрішніх травм художниці та кожної української жінки і суспільств у ијілому, а також влади і кордонів.

Описано основні засади акціонізму в межах заданої теми, а саме хеппенінги, зосереджені на темі нелояльності до ЛГБТ-спільноти, перформанси, пов'язані з рефлексіями анексії і війни з Росією, та переосмислення власного тіла в рамках естетичних канонів та булінгу сучасності.

Написано про введений художницею власний термін «перформативна скульптура», як результат ії довготривалої роботи над дослідженням скульптур та їх інтеграції в інші види мистецтва, а також про втілення розповсюдженого прийому сучасного мистеитва практики відтворення та «вдивляння в себе», яка реалізується у творчості багатьох художників епохи модерну та контемпопари, які можна спостерігати у творах Сальвадора Далі, Фріди Кало, Марка Квіна, Джеффа Кунса та інших митиів.

Роботи Марії ведуть глядача в сконструйовану нею реальність, де тіло, чуттєвість, щиирість, квірність, фемінність, нова ідентичність і героїзм перемагають дитячі травми, страхи і конфлікти, породжені турбулентним світом. Основним аспектом ї̈ творчості є ї̈ власне тіло, для неї принципово взагалі не використовувати чуже жіноче тіло, цее, на ї̈ думку, принщипова відмінність від усієї історії мистецтва. Вона відмовилася від використання моделі, підрядників та обслуговуючого персоналу, тобто жоден з етапів створення робіт не пов'язаний з кимось, окрім неї.

Досліджено відтворення тілесності та проблематика нової ідентичності завдяки різним художнім засобам, перформативним актам та серії скульптур із нетипових матеріалів, таких як жир, силікон, сіль, иукор, карамель, бетон, різні органічні мінерали, чавун, смоли і всілякі «начинки», такі як ланцюг, рослини або кулі та основи, виготовленої переважно з мила. Описано стратегію використання недовговічних матеріалів як концептуальне рішення, метафору крихкості, незахищеності, ефемерності людського тіла.

Ключові слова: образ жінки, фемінізм, образотворче мистецтвво, скульптура, відео-арт, перформанс.

Tatiana MELNIK, orcid.org/0000-0002-1667-9383 Graduate Student of the $2^{\text {nd }}$ year of Study Institute of Contemporary Arts of the National Academy of Arts of Ukraine (Kyiv, Ukraine) ttvmlk@gmail.com

\section{PROBLEMS OF FEMALE IMAGE IN THE WORK OF MARIA KULIKOVSKAYA}

The article is devoted to the topic of illuminating the image of a woman in the works of Ukrainian artist Maria Kulikovska.

Based on the analysis and systematization of scientific and journalistic sources, the specifics of contemporary art in Ukraine were described, which raises sociologically important topics in aspects of female imagery and corporeality in various arts, authored by Maria Kulikovskaya, namely: video art, sculpture, drawings and performative practices.

The works affecting the interpretation of femininity in relation to the personal internal traumas of the artist and each Ukrainian woman and society as a whole, as well as the authorities and borders, have been studied.

The basic principles of actionism within the given theme are described, namely, happenings focusing on disloyalty to the LGBT community, performances related to reflections on annexation and war with Russia and rethinking one's own body within the aesthetic canons and bullying of today.

It is written about the artist's own term "performative sculpture", as a result of her long-term work on the study of sculptures and their integration into other arts. 
Also, the embodiment of the common technique of contemporary art is the practice of rejection and "self-reflection", which is realized in the works of many artists of the Art Nouveau and contemporaries, which can be seen in the works of Salvador Dali, Frida Kahlo, Mark Quinn, Jeff Koons and other artists.

Maria's works lead the viewer into the reality constructed by her, where the body, sensuality, sincerity, ugliness, femininity, new identity and heroism overcome children's traumas, fears and conflicts caused by the turbulent world.

The main aspect of her work is her own body, for her it is fundamental not to use someone else's female body at all, in her opinion, this is a fundamental difference from the whole history of art. She refused to use models, contractors and service personnel, is none of the stages of the creation of works are related to anyone but her.

The reproduction of corporeality and the problems of new identity through various artistic means, performative acts and a series of sculptures made of atypical materials, such as fat, silicone, salt, sugar, caramel, concrete, various organic minerals, cast iron, resins and various "fillings", such as chains, plants or balls and bases made mainly of soap. The strategy of using short-lived materials as a conceptual solution, a metaphor of fragility, insecurity, ephemerality of the human body is described.

Key words: image of a woman, feminism, sculpture, video art, performance.

Постановка проблеми. Тематика жіночої образності в українському мистецтві, як не дивно, розкривається у творчості переважно мисткинь жіночої статі, особливо коли йдеться про прагнення зобразити дійснуреальність сьогодення, звернути увагу на соціальні проблеми та нову гендерну ідентичність.

Однією з найцікавіших авторок цього напряму $€$ Марія Куліковська.

Аналіз досліджень. Творчості Марії Куліковської присвячено декілька статей на спеціалізованих сайтах та нариси про ії творчість у збірниках, таких як «Marry me», «Pernament Revolution Ukrainian Art Today 2018» від «Zenko Foundation» та «Art WORK» Аліси Ложкіної.

Відчутний значний брак публікацій на зазначену тему через те, що художниця $є$ представницею сучасного українського мистецтва, описані роботи були створені за останні декілька років та стосуються гострих, табуюваних у суспільстві соціальних тем.

Мета статті - описати творчість Марії Куліковської, що розкриває теми феміністичного мистецтва в Україні та жіночої образності.

Виклад основного матеріалу. Основною творчою особливістю Марії Куліковської є те, що художниця не тільки звертається до часто «незручного» для комерційного попиту мистецтва, але й до нетривіальних матеріалів і технік, що підсилює ефект від сприйняття задуму твору. Вона завжди експериментує зі своїм тілом і матеріалом у діалозі з контекстом і простором. В її творчості завжди фігурує вона сама, їі творчість, історії та їх інтерпретації, відношення між тілом жінки і владою з їі кордонами. Основним аспектом творчості Марії Куліковської $є$ власне тіло, вона каже, що для неї принципово взагалі не використовувати чуже жіноче тіло, це, на ii думку, принципова відмінність від усієї історії мистецтва. Вона відмовилася використовувати моделі, підрядників та обслуговуючий персонал, тобто жоден з етапів створення робіт не пов'язаний $з$ кимось, окрім неї.
Художниця народилася в Криму, але зараз живе між європейськими містами та Києвом. Вона стала відомою не тільки в Україні, а й за ії межами, за останні півроку іï виставки відбулися у Відні, Лондоні, Копенгагені та Сантьяго-де-Компостела. Європейський досвід вплинув на її творчість та умовну відвертість в аспекті широкого розуміння фемінізму та рефлексії на тему жіночого тіла.

Її мистецтво - про те, що значить бути жінкою і жити в сучасній Україні. Однією з відоміших спроб художниці розкрити цю тему стала серія зліпків свого тіла з найнесподіваніших матеріалів: у хід ідуть жир, силікон, сіль, цукор, карамель, бетон, різні органічні мінерали, чавун, смоли і всілякі «начинки», такі як ланцюги, рослини або кулі та основа, виготовлена 3 мила.

Практика «вдивляння в себе» - поширений прийом сучасності: на кшталт Селфі, висхідна до творчості Фріди Кало, Сальвадора Далі, Джеффа Кунса та експериментів зі злитками голови з власної крові Марка Квіна у його проекті «Self», це почуття, знайоме кожній людині й жінці тем паче. 3 цієї лише точки зору проект є вдалим та влучним.

Перший зліпок художниця створила в кінці 2009 - на початку 2010 року. Це була свого роду рефлексія й одночасно психотерапія: реакція на багато несправедливості по відношенню до жінки в умовах українського патріархального суспільства. Вона пише, що на той момент в неї були дуже нездорові відносини 3 колишнім чоловіком, протистояти яким не було сил - iї мало хто підтримував, адже в нашому суспільстві ще панує ідея про те, що неправильно розлучатися, треба максимально довго терпіти, зберігати сім'ю, та начебто в аб'юзивному ставленні до себе часто винувата жінка, адже «заслужила», до того нова хвиля фемінізму ще тільки доходила до країни. Марія називає ці роботи інтуїтивною формою протесту, це дуже особиста історія, візуальний код якої розкриває складну для розуміння та сприйняття тематику, вона розуміла, що ставлення до жінки як 
такої ненормальне, адже звичайне людське тіло таке як $\epsilon$, з усіма вадами, сприймається нездорово.

На виникнення ідеї вплинуло дитинство художниці, вона виросла біля руїн давньогрецького городища Пантікапей і кожен день по дорозі до школи спостерігала за руїнами, травмованими тілами того, що колись було величним, вона каже, що патина часу і контекст робили їх ще красивішими.

Стародавні греки використовували статуї жіночих тіл (каріатиди) для того, щоб підтримувати конструкцію будівлі, тим самим надаючи досить жорстоку і патріархальну конотацію жінці, що утримує всю вагу і міць будівлі, тримаючи іiі на своїх плечах. Все це було нагадуванням про місце в суспільстві кожної реальної жінки та ії покарання. Щоденне зчитування цих рис культурного коду, а також реальне спостереження за тим, як важко працюють жінки, за частою відсутністю їх гідного визнання, викликали в художниці зробити це провідною темою власних творів.

У березні 2010 року М. Куліковська запропонувала перший зліпок на виставку до Восьмого березня в академію НАОМА, де була студенткою третього курсу архітектурного факультету. Роботу не прийняли, сказавши, що це - жахливо, аморально, і що замість оголеного жіночого тіла потрібні квіти або щось абстрактне: «Ми святкуємо Восьме березня, а не фемінізм» («Моя шкіра - моя справа», 2019: 3). Це досить яскраво ілюструє стан сприйняття контексту феміністичної проблематики, а також підміну понять в аспекті суті зазначеного свята. Але роботу прийняла галерея «Bottega», в якій проходив конкурс «МУХі», і скульптуру не тільки відібрали - художниця стала фіналісткою.

Тепер ці скульптури за останні пару років можна було побачити майже всюди: від «Мистецького Арсеналу» і магазину «Всі. Свої» на Хрещатику до садів в іспанській Галісії.

У 2010 році перша скульптура була $з$ гіпсу, бо в неї не було грошей на мармур або камінь. Зараз стратегія використання недовговічних матеріалів - концептуальне рішення, як метафора крихкості, незахищеності, ефемерності людського тіла.

«Для того щоб відформувати себе, я використовую класичний метод зняття гіпсової форми 3 живого тіла, що стоїть нерухомо, - розповідає авторка. Мій асистент, він же моя муза, забризкує мою шкіру холодним рідким гіпсом. Коли кірка 3 гіпсу починає тверднути, вона вступає в реакцію, що супроводжується високою температурою, перетворюється в камінь і фіксує всі відбитки, нерівності, деформації та структуру мого тіла. Це досить травматичний досвід. Доводиться стояти нерухомо дуже довго, годинами, терпіти зміни температури аж до опіків на шкірі, а також боротися з власними страхами в замкнутому просторі - по суті всередині каменю. Під час формування тіло іноді може набрякати. У підсумку кожна з готових скульптур - унікальний клон, не схожий на інші» (Мильна опера: арт-проект Марії Куликовської для Vogue UA, 2018: 1).

Те, що спочатку здавалося художниці цікавим дівочим нарцисизмом, поступово сформувалося в багаторічний проект-дослідження.

Кілька років тому художниця шокувала публіку, заявивши, що вступає в шлюб зі шведською дівчиною. Вони познайомились влітку 2013 року під час художнього обміну між митцями зі Швеції та України.

Цим жестом вона хотіла привернути увагу до проблем, з якими стикаються громадяни України в Свросоюзі: вічна тяганина з документами і відчуття себе людьми другого сорту. Найпростіший вихід із ситуації-вступити в шлюб з кимось із місцевих, чим часто користувались люди 3 минулого СНГ, заробивши неоднозначну славу за кордоном. I ось Марія Куліковська вирішує влаштувати так званий хеппенінг на зазначену тему та ще й тим самим епатує досі нелояльну до ЛГБТ-спільноти публіку в нашій країні. Вони були одружені три роки, в цей період художниця зосередилася на перформансах, пов'язаних з рефлексіями анексії і війни, а після розлучення зі своєю дружиною на ім'я Жаклін вона відновила роботу над зліпками.

Ще однією зі знакових та важливих подій в аспекті ii творчості, що пов'язана 3 темою жінок, була акція «Квіти демократії», що відбулася 2 серпня 2015 року біля згарища кінотеатру «Жовтень» на Подолі.

За задумом художниці дівчата в строгих чорних костюмах $\mathrm{i} з$ червоною помадою на губах повинні були прибивати заздалегідь приготовані гіпсові зліпки жіночих статевих органів до дерев'яних брусів тимчасового тунелю біля будівництва на території кінотеатру. Ідеєю акції було виявлення патріархальності українського суспільства і застосування подвійних стандартів як у політичному, так і в широкому соціальному дискурсі. Авторка звертається до історії зі спаленням кінотеатру, який показав неготовність суспільства до реальних демократичних змін. Як відомо, однією $з$ можливих причин спалення кінотеатру став показ у ньому фільмів на ЛГБТ-теми. Достовірність цього припущення неясна, що, втім, не заважає йому бути таким собі «амортизатором» для суспільства в легітимації спалення «Жовтня». Назва «Квіти демократії» має відсилку до Джозефа Бойса і його «Рози прямої демократії». 
У творчості Куліковської сьогодні дві головні теми: тіло і політика. Вона важко пережила анексію Криму і присвятила цій темі кілька акцій і перформансів. Найбільш відомий проект «Пліт Крим». Це реальний пліт, на якому у 2016 році художницю сплавляли по Дніпру поблизу Києва в пам'ять про тисячі людей, що після подій 2014 року позбулися рідного дому. У розпал військових дій на Сході країни сталася ще одна подія, яка сильно вплинула на творчість Марії Куліковської.

У момент коли донецький арт-центр «Ізоляція» був захоплений сепаратистами, там якраз проходила іiї виставка. Колишній арт-центр став одним 3 оплотів бойовиків - за чутками, в підвалі тримали полонених. До залишків сучасного мистецтва нові господарі «Ізоляції» проявили крайню ворожість. Скульптури Куліковської, тобто всі ті ж виливки іiі реального тіла, вони використовували як мішені на стрільбищі. Цей розстріл став важливим тригером для художниці, підштовхнувши іiі до створення в 2015 році резонансного проекту в лондонській галереї Саатчі. Тоді в рамках виставки українських художників повністю оголена Маша громила молотком свої скульптури, виконані з мила. Мило, з якого художниця робить свої роботи, виробляється в Швеції. Воно має таку ж щільність, як і людське тіло, й використовується як мішень на збройових заводах $\mathrm{i}$ стрільбищах. Цей перформанс був символічною відповіддю бойовикам, реакцією на розстріл художньої виставки, а також звільненням від болю і травм, завданих особисто Маші війною та анексією Криму, але й водночас і традиційним зверненням до жіночого тіла через художні засоби.

У 2020 році, знову використовуючи зліпки, авторка створює колаборацію зі шведською художницею Олександрою Ларссон-Якобсон i режисеркою Аліною Гонтар - проект «Квіти». Як громадянки двох дуже різних країн - неоліберальної Швеції та все ще доволі патріархальної України - авторки вже не один рік паралельно досліджують поняття людської оболонки як метафору соціально-політичних взаємин у суспільстві.

Образне і змістове наповнення проекту було зумовлено запропонованим комплексним поняттям Тіло-Шкіра-Оболонка-Мембрана-Шкура-Колір жінки. У назві проекту також закладена багатозначність російського слова иъветы, яке співзвучне до слова «цвета» (українською квіти і кольори). Проект зачіпає інтерпретацію фемінності відносно особистих внутрішніх травм і суспільства, влади і кордонів, материнства і його відсутності через власний шлях художниць.
Олександра два роки фотографує квіти, що в'януть, гниють, засихають - щойно зрізані, але вже вмираючі. Цю серію вона почала в той період, коли народила дитину. Фотографії спочатку були своєрідною рефлексією на трансформацію іï життя і тіла, новий статус у суспільстві, а також свого роду підсвідомою психологічною терапією і способом звільнитися від внутрішніх страхів і травм пам'яті (Сайт художниці Марії Куліковської, 2020: 2).

Проект складався із цілої низки тематичних робіт. Роботи Марії ведуть глядача в сконструйовану нею реальність, де тіло, чуттєвість, щирість, квірність, фемінність, нова ідентичність і героїзм перемагають дитячі травми, страхи і конфлікти, породжені турбулентним світом. Експозицію становили акварельні малюнки, створені багряною фарбою, що наче кровоточать на старому папері для архітектурних креслень, бюсти художниці 3 балістичного мила і квітів. А також відео, де Марія стріляє в безліч самих себе й оголена блукає в лісі. Художниця тікає від травматичного досвіду у власний ліс квітів, при цьому оголюючи ретельно приховані скелети в шафах глядача і суспільства.

Ще один відомий перформанс художниці, що має назву «Омовіння/Lustration», був представлений глядачам у «Мистецькому Арсеналі» дуже символічно -8 березня, в Міжнародний жіночий день. Він представляв собою холодну ванну, в якій знаходилася художниця та мильний зліпок їі тіла. Вона пояснює свій проект так: «Люстрація - це очищення за допомогою жертвопринесення. Протягом двох годин я приймала ванну 3 крижаної води на сцені «Мистецького Арсеналу», але разом зі мною у ванні перебувала і змилювалася точна копія мого тіла, мій клон. Змивати власне обличчя із самої себе - це дуже боляче: і фізично, і морально» (Мильна опера: арт-проект Марії Куліковської, 2018: 1).

Такий підхід $є$ характерним для мистецтва Середньовіччя, коли популярності набуло зображення монахів-столпників (свідчення про подвиги стояння на стовпі заради благочестя зустрічаються ще раніше IV століття), що обирали такий вид самопожертви, заключивши себе в стовп та читаючи молитви, поки їхнє тіло страждало і зазнавало смертельних мук, та зображення розп'яття в найбільш яскравих рисах, адже в ті часи потворне вважалося частиною гармонійного задуму Всевишнього. 3 тих пір тематика самопожертви набула втілення і розповсюдження в різних напрямах.

Незважаючи на фізичний дискомфорт, який завдає втілення цього проекту художниці, виглядає цей процес дуже ніжно та еротично. Марія Куліковська пестить свою мильну копію, обіймає, 
поливає іiї із золотого глечика - це викликає відчуття несвідомої алюзії до сюжету омовіння, зачіпає табуювану в пострадянському суспільстві тему любові до себе та її фізичних проявів, а також несе в собі вуаєристський ефект взаємодії 3 глядачем. Але попри те, що ця тантрична процесія сповнена любові до себе, художниця каже, що в основі подібних пошуків є спроба прийняття себе в клішейованому патріархальному світі, що обмежує, а іноді й морально катує жінку через жорсткі естетичні ідеали й очікування. Вона критикує потужне обожнювання жіночої краси, об'єктивацію краси і і1ї патріархальне сприйняття. Художниця каже, що це ображало iї та стало причиною таких доволі радикальних маніфестацій, аби для себе визначити, хто вона така та чи має право на власне тіло, на те, яке $\epsilon$.

Після перформансу в «Арсеналі» мисткиня вирішила зробити його ще 88 раз у різних країнах, локаціях і контекстах. Другий раз вона повторила його для українського журналу «Vogue», де він був збережений на відео, зйомка якого тривала більше 8-ми годин поспіль (Канал «Vogue Ukraine», 2018: 4).

Художницею був уведений власний термін «перформативна скульптура», як результат ii довготривалої роботи над дослідженням скульптур із нетрадиційних матеріалів та їх інтеграції в інші види мистецтва.

Діяльність авторки виходить за рамки виключно мистецтва. 32015 року Куліковська заснувала мистецький колектив та відкриту феміністичну платформу «Квіти Демократії» (серія акцій у Києві, Дніпрі, Лондоні, Каунасі). Марія та Улег (ії чоловік та асистент) у травні 2017 р. офіційно заснували Громадську Організацію «Школа
Політичного Перформансу» в Києві. 32020 р. Марія з Улегом побудували та відкрили першу Галерею-Сховище «Гараж 33» для художників із «конфлікту» в Києві, актуалізуючи та рефлексуючи на таке поняття, як «тіло з конфлікту», та надаючи голос маргіналізованим групам суспільства.

Висновки. Підсумовуючи зазначене вище, можемо констатувати, що творчість та діяльність Марії Куліковської є знаковою для української культури, адже тенденція останніх років на всесвітньому ринку яскраво ілюструє, що попит має комерційно ангажоване мистецтво, а релевантність щодо соціально гострих тем часто лишається поза увагою митців, адже потребує фінансового альтруїзму та сміливості.

Художниця скаржиться на те, що иї роботи досі часто не сприймаються арт-системою через нетривіальну, милу та зручну тематику. Вони не піддаються прямій цензурі, скоріше ігноруються як професійною українською культурною спільнотою, що складається із старшого покоління художників та критиків, так і тими, хто розподіляе фінанси, гранти та представляє умовне офіційне українське мистецтво, оскільки ігнорування - найкращий спосіб знищити когось, зробіть його/її невидимим і беззвучним. Ще один із найпоширеніших методів «репресій» мистецтва - це блокування ii публікацій та фотографій у соціальних мережах.

До того ж, аналізуючи мистецтво України періоду незалежності в контексті гендерної та особливо феміністичної тематики, стає очевидним, що вона освітлюється виключно жінками-художницями, яких на арт-ринку значно менше, аніж чоловіків, що також яскраво ілюструє гендерні реалії на ринку творчих спеціальностей.

\section{СПИСОК ВИКОРИСТАНИХ ДЖЕРЕЛ}

1. Арт-проект Марії Куліковської для «Vogue Ukraine». URL: https://vogue.ua/article/culture/art/art-proekt-mariikulikovskoy-dlya-vogue-ua.html

2. Сайт художниці Марії Куліковської «Maria Kulikovska». URL: https://www.mariakulikovska.net/ua

3. Говорить художниця: Марія Куліковська «Моя шкіра - моя справа». URL: https://www.prostranstvo.media/ govorit-hudozhnica-marija-kulikovskaja-moja-kozha-moe-delo/

4. Канал «Vogue Ukraine». URL: https://www.youtube.com/watch?v=eIs_xaGg-Lo\&feature=emb_title

5. Чому в українському мистецтві є великі художниці / Л. Герман та ї. Київ : Publish Pro Ltd̄., PinchukArtCentre, 2019. $224 \mathrm{c}$.

\section{REFERENCES}

1. Stattya «Art-proekt Marii Kulikovskoi dlia «Vogue Ukraine»» [The article «Maria Kulikovska's art project for «Vogue Ukraine»»]. https://vogue.ua/Retrieved from https://vogue.ua/article/culture/art/art-proekt-marii-kulikovskoy-dlyavogue-ua.html [in Russian].

2. Sait khudozhnytsi Marii Kulikovskoi «Maria Kulikovska» [Maria Kulikovska's website.] Retrieved from: https://www.mariakulikovska.net/ua [in Russian].

3. Hovoryt khudozhnytsia: Mariia Kulikovska, «Moia shkira - moia sprava» [The article «Says the artist: Maria Kulikovskaya, "My skin is my business»] https://www.prostranstvo.com Retrieved from https://www.prostranstvo.media/ govorit-hudozhnica-marija-kulikovskaja-moja-kozha-moe-delo/ [in Ukranian].

4. Kanal zhurnalu «Vogue Ukraine». [The channel of the magazine «Vogue Ukraine»]. https://www.youtube.com/ Retrieved from https://www.youtube.com/watch?v=eIs_xaGg-Lo\&feature=emb_title [in Russian].

5. Herman L.,. etc. Chomu v ukrainskomu mystetstvi ye velyki khudozhnytsi. [Why are there great artists in Ukrainian art]. Kyiv. Publish Pro Ltd., PinchukArtCentre, 2019. 224 p [in Ukraninan]. 